\title{
The marine algae Sargassum spp. (Sargassaceae) as feed for sheep in tropical and subtropical regions
}

\author{
Alejandro Marín ${ }^{1}$, Margarita Casas-Valdez ${ }^{1}$, Silvia Carrillo², Hugo Hernández ${ }^{3}$, Alberto Monroy³, \\ Leonor Sanginés ${ }^{2} \&$ Fernando Pérez-Gil ${ }^{2}$ \\ 1. Laboratorio de Macroalgas. Centro Interdisciplinario de Ciencias Marinas, Ave. Instituto Politécnico Nacional s/n, \\ Col. Playa Palo de Santa Rita, La Paz, Baja California Sur, México, phone: (612) 12253 44, ext. 82411; fax: (612) \\ 12253 22. Apdo. Postal 592. La Paz, B. C. S., México, C.P. 23090; mcasasv@hotmail.com, amarinal@ipn.mx \\ 2. Departamento de Nutrición Animal. Instituto Nacional de Ciencias Médicas y Nutrición Salvador Zubirán. Vasco de \\ Quiroga No.15, México, D. F., C.P. 14000; silviecarrillo3@hotmail.com; leosangines@hotmail.com; \\ rosyo@prodigy.net.mx \\ 3. Departamento de Zootecnia. Universidad Autónoma de Baja California Sur. Km 5 Carr. al Sur. La Paz, B. C. S., \\ México, C.P. 23050; amonroy@uabcs.mx; hehi@uabcs.mx
}

Recibido 13-XI-2008. Corregido 15-II-2009. Aceptado 16-III-2009.

\begin{abstract}
The objective of this study was to evaluate Sargassum meal as feed for sheep through the measures of in vivo digestibility, dry matter degradability, $\mathrm{pH}$, ammonia and volatile fatty acids in rumen. The Sargassum algae used in this experiment were collected at the end of spring, when they are more abundant, bigger, and have completed their reproductive cycle. Four tons (wet weigth) were collected manually from the intertidal zone of La Paz bay, Baja California Sur, Mexico. These algae were sun-dried and ground in a hammer mill to obtain the Sargassum meal. Four fistulated Pelibuey sheep, were fed daily with diets containing the marine algae (MA) at different levels $(0,10,20$ and $30 \%)$, using a 4 x 4 Latin-square design experiment. Feed intake was not affected $(\mathrm{p}>0.05)$. Water consumption and urine excretion increased with MA $\left(\mathrm{p}<0.05 ; \mathrm{r}^{2}=0.54\right.$ and $\mathrm{r}^{2}=0.74$, respectively). In all treatments dry matter digestibility was of $74 \%-79 \%$, and crude protein digestibility was of $85 \%-88 \%$. Acid detergent fiber (59\%-65\%) and neutral detergent fiber (55\%-66\%) digestibility were greater in all treatments with MA. Ruminal $\mathrm{pH}$ was greater in all groups fed with MA $(\mathrm{p}<0.05)$. Ammonium concentration was not influenced $(\mathrm{p}>0.05)$ by MA. Ruminal volatile fatty acids decreased in all MA groups $(\mathrm{p}<0.05)$. The marine algae Sargassum spp. can be used as a feed supplement for sheep, especially in tropical and subtropical regions where these marine algae are available. Rev. Biol. Trop. 57 (4): 1271-1281. Epub 2009 December 01.
\end{abstract}

Key words: marine algae, sheep, Sargassum, digestibility, ruminal fermentation, volatile fatty acids.

In Mexico as in other countries around the world, there are arid regions where sheep and goats are severely affected during the dry season because naturally-grown feed is scarce (Yahaya et al. 1999, Mora et al. 2009). The marine algae, Sargassum spp. represents an important alternative as food.

Sargassum forms large beds in tropical and subtropical waters around the world, growing along beaches with a rocky substrate, rolling stones and pebbles (Ganzon-Fortes et al. 1993).
This algae is especially abundant along the Gulf of California coast, where a harvestable amount of $183000 \mathrm{t}$ has been estimated (Casas-Valdez et al. 2006a). This genus is a good source of minerals, carbohydrates and some essential amino-acids like arginine, tryptophane and phenylalanine. It is also rich in beta-carotene and vitamins. Furthermore, no antinutritious elements have been detected in it (Carrillo et al. 2002, Casas-Valdez et al. 2006a). Some studies have shown a seaweed digestibility ranging 
from $28 \%$ to $67 \%$ (dry matter), and a protein degradability of $95 \%$ (Gojón et al. 1998).

Experimental works conducted with sheep and seaweeds are scarce. Arieli et al. (1993) mention that Ulva lactuca (Linnaeus) 1753 could be categorized as a low-energy highnitrogen foodstuff, and that these algae is a useful supplement for sheep. Hansen et al. (2003) concluded that Laminaria digitata (Hudson) J.V. Lamouroux 1813 and L. hyperborea (Gunnerus) Foslie 1884 can be used as an alternative food for north Ronaldsoy sheep. The effects of Sargassum spp. on digestibility and ruminal parameters in ruminants are unknown.

The objective of this study was to evaluate Sargassum meal as feed for sheep through the measures of in vivo digestibility, dry matter degradability, $\mathrm{pH}$, ammonia and volatile fatty acids in rumen.

\section{MATERIALS AND METHODS}

Algae and chemical analysis Sargassum spp.: Specimens were collected at the San Juan de La Costa beach, which is located in La Paz bay, Baja California Sur, Mexico $\left(24^{\circ} 27^{\prime}-24^{\circ}\right.$ $06^{\prime} \mathrm{N}$ and $110^{\circ} 18^{\prime}-110^{\circ} 40^{\prime} \mathrm{W}$ ). Four tons (wet weight) were collected manually from the intertidal zone at depths between $60 \mathrm{~cm}$ and $1.20 \mathrm{~m}$. Plants were spread on a cement surface and sun-dried for two days. Then the marine algae (MA) was ground in a hammer mill (JERZA, model L) and afterwards in a knife mill using a $1 \mathrm{~mm}$ mesh. A sample of $1 \mathrm{~kg}$ was taking by quartering, to grind it finely and carry out chemical analysis by triplicate (Table 1).

The following analyses were carried out on the Sargassum meal and diets using standard methods (AOAC 2000): moisture content (over-drying at $60^{\circ} \mathrm{C}$ to constant weigth, $\mathrm{AOAC}$ 2000 method 976.05), ash (ignition at $550^{\circ} \mathrm{C}$ in an electric furnace, AOAC 2000 method 923.03), nitrogen content was determined using the micro-Kjeldahl method (AOAC 2000 method 976.05), and a conversion factor of 6.25 was used to calculate protein content (CP), and ether extract (EE) (Soxhlet apparatus, AOAC 2000 method 920.39). Cell wall fractions: neutral detergent fibre (NDF), acid detergent fibre $(\mathrm{ADF})$, cellulose, hemicellulose and lignin were

TABLE 1

Ingredients and chemical composition ( $(\mathrm{g} / 100 \mathrm{~g}$ DM) of diets used

\begin{tabular}{|c|c|c|c|c|}
\hline Ingredients & $0 \%$ MA & $10 \% \mathrm{MA}$ & $20 \% \mathrm{MA}$ & $30 \% \mathrm{MA}$ \\
\hline Dehydrated alfalfa (12\% CP) & 50.40 & 48.00 & 42.20 & 28.00 \\
\hline Corn $(8 \% \mathrm{CP})$ & 32.50 & 23.50 & 17.50 & 20.80 \\
\hline Marine algae ${ }^{a}$ & 0.00 & 10.00 & 20.00 & 30.00 \\
\hline Soybean (45 \% CP) & 14.80 & 15.70 & 17.50 & 18.80 \\
\hline Urea & 0.30 & 0.30 & 0.20 & 0.30 \\
\hline Tallow & 2.00 & 2.50 & 2.60 & 2.10 \\
\hline Total & 100.00 & 100.00 & 100.00 & 100.00 \\
\hline \multicolumn{5}{|l|}{ Chemical composition } \\
\hline Organic matter & $94.09 \pm 1.77$ & $91.29 \pm 1.93$ & $88.70 \pm 2.16$ & $86.66 \pm 1.88$ \\
\hline Crude protein (g/100g) & $11.31 \pm 1.28$ & $10.69 \pm 1.65$ & $11.25 \pm 1.58$ & $11.07 \pm 1.71$ \\
\hline Neutral Detergent Fibre (\%) & $19.88 \pm 3.41$ & $19.85 \pm 3.65$ & $26.51 \pm 5.45$ & $26.53 \pm 4.23$ \\
\hline Acid Detergent Fibre (\%) & $15.04 \pm 2.64$ & $19.41 \pm 3.18$ & $21.33 \pm 4.12$ & $24.69 \pm 3.18$ \\
\hline Metabolizable Energy (Mj/kg) & $10.37 \pm 1.15$ & $10.24 \pm 1.03$ & $10.19 \pm 1.6$ & $10.32 \pm 1.71$ \\
\hline \multicolumn{5}{|c|}{$\begin{array}{l}\text { a Composition of Sargassum spp:: Moisture } 7.7 \pm 0.06 \% \text {, CP } 6.3 \pm 0.04 \% \text {, Ether extract } 0.45 \pm 0.03 \% \text {, CF } 6.4 \pm 0.08 \% \text {, } \\
\text { Ash } 33.3 \pm 0.11 \% \text {, GE } 2.13 \pm 0.02 \mathrm{kcal} / \mathrm{g} \text {, NDF } 47.1 \pm 0.42 \% \text {, ADF } 44.5 \pm 0.35 \% \text {, Cellulose } 6.2 \pm 0.37 \% \text {, Mg } 7.54 \pm 0.07 \mathrm{mg} / \mathrm{g} \text {, } \\
\mathrm{K} 15.9 \pm 0.06 \mathrm{mg} / \mathrm{g}, \mathrm{Na} 28.7 \pm 0.16 \mathrm{mg} / \mathrm{g} \text {, Ca } 6.41 \pm 0.094 \mathrm{mg} / \mathrm{g}, \mathrm{P} 2.7 \pm 0.07 \mathrm{mg} / \mathrm{g} \text {, Fe } 263 \pm 9.65 \mathrm{ppm}, \mathrm{Zn} 119 \pm 5.41 \mathrm{ppm}, \mathrm{Cu} \\
14 \pm 0.29 \mathrm{ppm}, \mathrm{Pb} 18 \pm 0.02 \mathrm{ppm} \text {, Se } 85 \pm 0.13 \mathrm{ppb}, \mathrm{Hg} 181 \pm 0.26 \mathrm{ppb} \text {, Tannic acid } 22 \pm 0.53 \mathrm{mg} / \mathrm{g} \text {, Saponines }++ \text {, Cianogenic } \\
\text { glucosides and Alkaloids not detected. NDF = Neutral detergent fiber; ADF = Acid detergent fiber. }\end{array}$} \\
\hline
\end{tabular}


analyzed according to the Van Soest method described by Tejada (1985), and gross energy was determined using a calorimetric Parr Bomb (Parr Instrument Bomb, Mod. 6300).

To determine $\mathrm{Ca}, \mathrm{Mg}, \mathrm{Na}, \mathrm{K}$ and $\mathrm{Fe}$ samples of MA meal were subjected to acid digestion and analyzed by atomic absorption spectrophotometry (Brand GBC, Mod. Avanta PM) following the procedures described by AOAC (2000) method 968.08 (Table 1). Zn and $\mathrm{Cu}$ by AOAC (2000) method 999.11. P was obtained by colorimetric (Clesceri et al. 1989, method 4500). Pb, Hg y Se (NOM-117SSA1-1994).

Metabolizable Energy (ME), Digestible Energy (DE) and Total Digestible Nutrients (TDN), were calculated: $\mathrm{ME}=\mathrm{D}$ $\mathrm{E} * 0.82 ; \mathrm{DE}=\mathrm{TDN} * 4409 \mathrm{kcal} ; \mathrm{TDN}=$ crude fiber $(0.5)+$ crude protein $(0.75)+$ nitrogen free extract $(0.75)+($ ethereal extract $(0.90 * 2.25))$.

Experimental designs: The diets utilized were: control diet ( $0 \% \mathrm{MA})$, diet supplemented with $10 \%, 20 \%$ and $30 \%$ of Sargassum spp. meal (10\% MA, 20\% MA and 30\% MA). The four diets met the sheep's nutritional requirements $(12.8 \%$ of crude protein and $10.19 \mathrm{Mj} /$ kg) (NRC 1996) (Table 1).

The study was conducted at La Paz City, Baja California Sur, Mexico. The weather in this region is typically warm and semi-arid, with an annual precipitation of $220 \mathrm{~mm}$, a $50 \%$ average humidity and a $28^{\circ} \mathrm{C}$ average temperature.

Four Pelibuey sheep (mean BW=24.5kg, 18 months old) fitted with ruminal cannulae (Plastisol 1"; Bar Diamond) were randomly distributed in a replicated 4 x 4 Latin-square design, and were kept in metabolism cages with restricted access to feeding. All animals were treated with anthelmintics. The experimental protocol was approved by the Scientific Committee of the Universidad Autónoma de Baja California Sur.

Feed $(0.600 \mathrm{~kg}$ of diet $)$ was provided twice a day at 06:00 and 18:00 hours. Water intake was provided ad libitum. Each one of the four experimental periods comprised 15 days; 10 days for diet-adaptation period, and 5 days for total feces and urine collection. feed intake (the difference between feed offered and feed refusal) and water intake were recorded daily. Total feces and urine were collected daily. In addition, dry matter (DM), CP, ADF and NDF digestibility (total fecal collection) were determined.

The DM digestibility coefficient of each diet was estimated using the following formula:

$$
\mathrm{DC}=\frac{\mathrm{FI}-\mathrm{FO}}{\mathrm{FI}} \times 100
$$

Where: $\quad \mathrm{DC}=$ digestibility coefficient $(\%)$; $\mathrm{FI}=$ feed intake (DM basis) and $\mathrm{FO}=$ fecal output (DM basis).

Rumen degradability of dry matter for each diet was determined in situ using a nylon bag technique. The nylon bags (224 of $10 \times 5 \mathrm{~cm}$; pore size $=60 \mu \mathrm{m}$ ) were filled with $3 \mathrm{~g}$ of each diet and suspended in the rumen of each sheep. The bags were incubated for $3,6,9,12,24,30$, 36,48 and 72 hours (zero time disappearance was obtained by suspending the nylon bags in a $\mathrm{NaCl} 0.15 \mathrm{~N}$ solution, at $37^{\circ} \mathrm{C}$ for $5 \mathrm{~min}$ ). Upon removal from the rumen, bags were washed five times during one min in a mechanical agitator until obtaining a clear and transparent rinsing liquid and afterwards, dried at $60^{\circ} \mathrm{C}$ and weighed (Harmon \& Richards 1997, Stern et al. 1997) before determining DM disappearance which was calculated as follows:

$$
\mathrm{DM}(\%)=\frac{((\mathrm{WB}+\mathrm{WBI})-(\mathrm{WB}+\mathrm{WAI}))}{\mathrm{SW}} \times 100
$$

Where: $\mathrm{DM}(\%)=$ dry matter disappearance; $\mathrm{WB}=$ bag weight; $\mathrm{WBI}=$ sample weight prior to incubation; $\mathrm{WAI}=$ sample weight after incubation; $\mathrm{SW}=$ sample weight.

Result of the in situ digestibility of DM were fitted to the non-linear equation: $\mathrm{P}=$ $\mathrm{a}+\mathrm{b}\left(1-\mathrm{e}^{-\mathrm{ct}}\right)$ (Orskov \& McDonald 1979) using the Neway Excel program, where: $\mathrm{P}=$ disappeared at time $t ;(\mathrm{a}+\mathrm{b})=$ potential degradability; 
$\mathrm{c}=$ rate of degradation. The effective degradation was estimated at different degradation rates (fraction $\mathrm{h}^{-1}$ ): 0.02, 0.05 and 0.08 .

Ruminal content samples of $150 \mathrm{ml}$ were collected at 03:00, 06:00, 09:00, 12:00, 18:00 and 24:00 $\mathrm{hr}$ through the ruminal cannulae, for five days. One portion of the ruminal content was filtered by squeezing out eight layers of gauze and the $\mathrm{pH}$ of the filtrate was recorded immediately using a potentiometer (Orion Mod. 701A) with a Corning electrode (AOAC 2000). Ammoniacal nitrogen was determined by the distillation method (Clesceri et al. 1989, method 4500). To determine volatile fatty acids (VFA's), $5 \mathrm{ml}$ of filtrate were mixed with $1 \mathrm{ml}$ of a 3:1 (25\%) metaphosphoric acid/formic acid solution followed by centrifugation at 2 $300 \mathrm{~g}$ for $30 \mathrm{~min}$, then the supernatant was frozen and stored until analyzed. VFA's content were determined using a Varian Star 3400 CX chromatograph (AOAC 2000, method 996.06). Data were analyzed by triplicate.

Statistical analysis: Data of digestibility in vivo, kinetic of digestibility in situ of dry matter, feed and water intake, and urine excreted were examined using analysis of variance with a Latin square design (4 x 4) (Kuehl 1999) and Tukey's test for a multiple comparisons of means, with a significance level of $\mathrm{p}<0.05$.
Correlation analysis was made to know if there was a relationship between the concentration of Sargassum in the diet and: a) water intake, b) urine excretion, as well as between water intake and urine excretion. Ruminal $\mathrm{pH}$, ruminal ammonia, and VFA data were analyzed as repeated measures using the Statistical Analysis System program (SAS 1985).

\section{RESULTS}

Digestibility: No significant difference was found in feed intake among all experimental diets $(p>0.05)$ (Table 2). There was significant difference in water intake and urine excretion between the control diet and the diets with MA $(p<0.05)$. A progressive increase in water intake $\left(\mathrm{r}^{2}=0.54\right)$ and urine excretion $\left(\mathrm{r}^{2}=0.74\right)$ (Table 2) was observed as the concentration of MA added in the diets increased; a positive correlation $\left(\mathrm{r}^{2}=0.80\right)$ was found between water intake and urine excretion. Feces output did not present significant difference among all experimental diets $(p>0.05)$; however, the feces output of the animals fed with the diets $20 \%$ and 30\% MA were more humid.

The in vivo digestibility coefficient of $\mathrm{DM}$ and CP showed no significant differences among control diet and the diets with MA ( $p>0$ .05 ) (Table 2). The digestibility of ADF of the

TABLE 2

Feed intake, water consumption, feces output and urine excreted, dry matter (DM), crude protein (CP), acid detergent fiber $(A D F)$ and neutral detergent fiber (NDF) digestibility in ewes fed diets supplemented with Sargassum spp.

\begin{tabular}{lccccc} 
& \multicolumn{3}{c}{ Treatments } & & \\
& $0 \% \mathrm{MA}$ & $10 \% \mathrm{MA}$ & $20 \% \mathrm{MA}$ & $30 \% \mathrm{MA}$ & SEM \\
Feed intake-DM (kg/d) & $1.15 \pm 0.09^{\mathrm{a}}$ & $1.15 \pm 0.10^{\mathrm{a}}$ & $1.20 \pm 0.07^{\mathrm{a}}$ & $1.11 \pm 0.08^{\mathrm{a}}$ & 0.18 \\
Water consumption (1/d) & $3.45 \pm 0.74^{\mathrm{a}}$ & $4.26 \pm 0.88^{\mathrm{b}}$ & $4.84 \pm 0.70^{\mathrm{c}}$ & $4.87 \pm 0.48^{\mathrm{bc}}$ & 0.38 \\
Urine excreted (1/d) & $0.59 \pm 0.29^{\mathrm{a}}$ & $0.99 \pm 0.36^{\mathrm{b}}$ & $1.14 \pm 0.28^{\mathrm{b}}$ & $1.57 \pm 0.44^{\mathrm{c}}$ & 0.20 \\
Feces output-DM (kg/d) & $0.26 \pm 0.07^{\mathrm{a}}$ & $0.24 \pm 0.03^{\mathrm{a}}$ & $0.27 \pm 0.04^{\mathrm{a}}$ & $0.28 \pm 0.07^{\mathrm{a}}$ & 0.03 \\
DM coefficient of digestibility & $0.77 \pm 0.02^{\mathrm{a}}$ & $0.79 \pm 0.02^{\mathrm{a}}$ & $0.77 \pm 0.04^{\mathrm{a}}$ & $0.74 \pm 0.03^{\mathrm{a}}$ & 0.02 \\
CP coefficient of digestibility & $0.87 \pm 0.01^{\mathrm{a}}$ & $0.88 \pm 0.01^{\mathrm{a}}$ & $0.86 \pm 0.02^{\mathrm{a}}$ & $0.85 \pm 0.01^{\mathrm{a}}$ & 0.01 \\
ADF coefficient of digestibility & $0.3 \pm 0.04^{\mathrm{a}}$ & $0.59 \pm 0.07^{\mathrm{b}}$ & $0.64 \pm 0.04^{\mathrm{b}}$ & $0.65 \pm 0.04^{\mathrm{b}}$ & 0.02 \\
NDF coefficient of digestibility & $0.44 \pm 0.07^{\mathrm{b}}$ & $0.55 \pm 0.08^{\mathrm{ab}}$ & $0.67 \pm 0.05^{\mathrm{a}}$ & $0.66 \pm 0.07^{\mathrm{a}}$ & 0.03
\end{tabular}

${ }^{a, b, c}$ Different letters in each row indicate statistically significant differences $(p<0.05)$. 
control diet was smaller in regard to all other treatments $(\mathrm{p}<0.05)$. Moreover, the digestibility of NDF was greater in the $20 \%$ and $30 \%$ MA compared to the control diet $(\mathrm{p}<0.05)$.

Dry matter disappearance: During the ruminal incubation of diets, no significant differences were found in the DM disappearance among treatments in the first 24 hours ( $>0.05$ ), but from 48 to $72 \mathrm{hr}$ the disappearance of the control diet was higher (Fig. 1). Differences were observed in each treatments as time passed by $(\mathrm{p}<0.05)$, DM disappearance increased with time of incubation.

Kinetics of the in situ digestibility of DM: The soluble fraction (a) exhibited significant difference between the control diet and the diet with $30 \%$ MA which is higher $(\mathrm{p}<0.05)$. The potentially digestible fraction (b) was higher in control diet than $10 \%$ MA $(p<0.05)$, but there was not significant difference in relation to $20 \%$ and $30 \%$ MA. Not any significant difference was found between the diets in the potential degradability $(p>0.05)$. No significant difference was found among the diets in degradability rate (Rate constant (fraction/hr)) $(p>0.05)$. The effective degradation was higher $(p<0.05)$ at the lowest degradation rate $(0.02 /$ $\mathrm{hr}$ ) in all treatments (Table 3).

pH, ammonia and volatile fatty acids in the rumen: The lowest $\mathrm{pH}$ value was recorded on the control diet $(\mathrm{p}<0.05)$, compared to the diets with MA, therefore Sargassum spp. meal favoring a neutral $\mathrm{pH}$ (Table 4). Patterns of $\mathrm{pH}$ variation were similar among treatments.

No differences were observed in ammonia concentration among treatments $(\mathrm{p}>0.05)$ (Table 4). Ruminal $\mathrm{NH}_{3}$ concentration $(\mathrm{mg} / \mathrm{l})$ was of 215 in the control group, and varied between 221 and 265 in the treatments with MA.

Acetic acid declined in all treatments 12 hours after the first meal (Table 5). Significant differences $(\mathrm{p}<0.05)$ were observed among $20 \%$ and $30 \%$ MA whose concentration was smaller than the control group. Propionic acid also displayed a similar pattern (Table 5), with

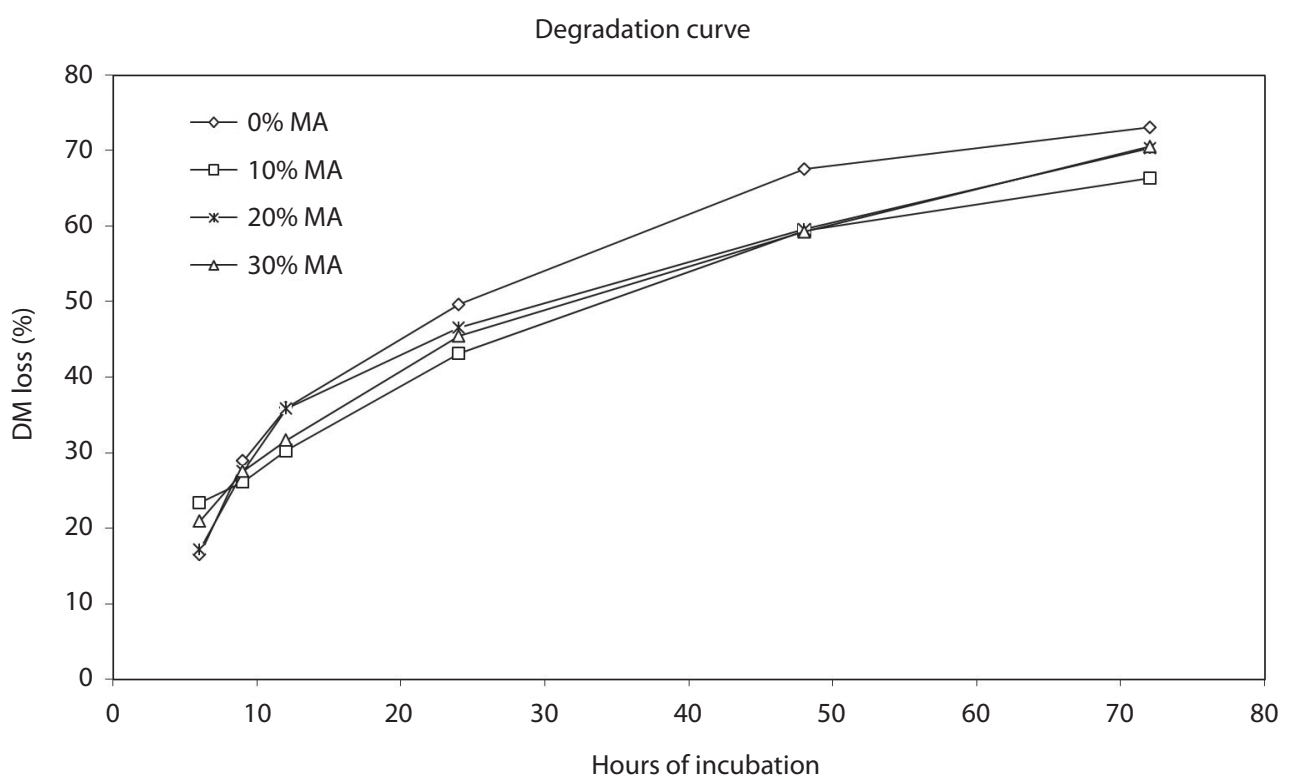

Fig. 1. Ruminal dry matter disappearance of: control diet (0\% MA), diet supplemented with 10\% of Sargassum spp. (10\% MA), diet supplemented with $20 \%$ of Sargassum spp. (20\% MA) and, diet supplemented with $30 \%$ of Sargassum spp. (30\% MA). 
TABLE 3

Kinetics of the in situ disappearance of dry matter from experimental diets

\begin{tabular}{|c|c|c|c|c|}
\hline Treatments & $0 \%$ MA & $10 \% \mathrm{MA}$ & $20 \% \mathrm{MA}$ & $30 \% \mathrm{MA}$ \\
\hline Soluble fraction (a) (\%) & $7.42 \pm 0.94^{b}$ & $10.27 \pm 2.06^{\mathrm{ab}}$ & $11.03 \pm 1.69^{\mathrm{ab}}$ & $12.54 \pm 1.71^{\mathrm{a}}$ \\
\hline Fraction (b) $(\%)$ & $72.87 \pm 2.72^{\mathrm{a}}$ & $59.57 \pm 4.51^{b}$ & $62.35 \pm 5.32^{\mathrm{ab}}$ & $64.55 \pm 10.31 \mathrm{ab}$ \\
\hline Potential degradability (\%) & $80.27 \pm 2.45^{\mathrm{a}}$ & $69.80 \pm 6.38^{\mathrm{a}}$ & $73.40 \pm 6.10^{\mathrm{a}}$ & $77.20 \pm 11.13^{\mathrm{a}}$ \\
\hline Rate constant (fraction/hr) & $0.036 \pm 0.01^{\mathrm{a}}$ & $0.036 \pm 0.005^{\mathrm{a}}$ & $0.033 \pm 0.005^{\mathrm{a}}$ & $0.029 \pm 0.005^{\mathrm{a}}$ \\
\hline \multicolumn{5}{|c|}{ Effective degradability (\%) at different disappearance rates $\mathrm{Kd}\left(\mathrm{hr}^{-1}\right)$ : } \\
\hline 0.02 & $53.82 \pm 3.87^{\mathrm{aA}}$ & $48.35 \pm 2.79^{\mathrm{bA}}$ & $50.025 \pm 3.48 \mathrm{abA}$ & $50.30 \pm 5.24^{\mathrm{abA}}$ \\
\hline 0.05 & $37.70 \pm 4.06^{\mathrm{aB}}$ & $35.05 \pm 1.69 \mathrm{aB}$ & $36.07 \pm 2.30^{\mathrm{aB}}$ & $35.92 \pm 3.33^{\mathrm{aB}}$ \\
\hline 0.08 & $29.92 \pm 3.47 \mathrm{aB}$ & $28.87 \pm 1.91^{\mathrm{aB}}$ & $29.47 \pm 1.73 \mathrm{aB}$ & $29.52 \pm 2.70^{\mathrm{aB}}$ \\
\hline
\end{tabular}

${ }^{a, b}$ Different letters within each row indicate significant differences $(\mathrm{p}<0.05)$.

${ }^{A}, \mathrm{~B}$ Different letters within each column indicate significant differences $(\mathrm{p}<0.05)$.

TABLE 4

Patterns of variation of ruminal $\mathrm{pH}$ and ruminal ammonia concentration ( $\mathrm{mg} / \mathrm{l})$ over a $24 \mathrm{hr}$ period in sheep supplemented with Sargassum spp.

\begin{tabular}{cccccc} 
& \multicolumn{5}{c}{$\mathrm{pH}$} \\
Hour & $0 \% \mathrm{MA}$ & $10 \% \mathrm{MA}$ & $20 \% \mathrm{MA}$ & $30 \% \mathrm{MA}$ & SEM \\
0300 & $6.61 \pm 0.52$ & $6.80 \pm 0.49$ & $6.95 \pm 0.39$ & $6.74 \pm 0.58$ & 0.07 \\
0600 & $6.53 \pm 0.42$ & $6.65 \pm 0.55$ & $6.82 \pm 0.45$ & $6.82 \pm 0.51$ & 0.07 \\
0900 & $6.32 \pm 0.57$ & $6.55 \pm 0.67$ & $6.64 \pm 0.62$ & $6.66 \pm 0.60$ & 0.08 \\
1200 & $6.51 \pm 0.48$ & $6.69 \pm 0.52$ & $6.69 \pm 0.69$ & $6.79 \pm 0.58$ & 0.06 \\
1800 & $6.86 \pm 0.26$ & $7.03 \pm 0.41$ & $7.11 \pm 0.43$ & $7.14 \pm 0.27$ & 0.06 \\
2400 & $7.15 \pm 0.18$ & $7.18 \pm 0.36$ & $7.38 \pm 0.22$ & $7.24 \pm 0.14$ & 0.05 \\
Mean & $6.61 \pm 0.14^{\mathrm{a}}$ & $6.81 \pm 0.12^{\mathrm{b}}$ & $6.93 \pm 0.16^{\mathrm{b}}$ & $6.89 \pm 0.17^{\mathrm{b}}$ & \\
& & $\mathrm{Ammonia}, \mathrm{mg} / 1$ & & \\
Hour & $0 \% \mathrm{MA}$ & $10 \% \mathrm{MA}$ & $20 \% \mathrm{MA}$ & $30 \% \mathrm{MA}$ & $\mathrm{SEM}$ \\
0300 & $235.1 \pm 54.8$ & $378.1 \pm 218.9$ & $316.9 \pm 177.8$ & $368.2 \pm 128.6$ & 0.41 \\
0600 & $234.1 \pm 116.0$ & $190.6 \pm 122.0$ & $218.0 \pm 157.6$ & $353.6 \pm 203.7$ & 0.45 \\
0900 & $177.0 \pm 142.3$ & $235.8 \pm 196.6$ & $337.3 \pm 186.3$ & $328.1 \pm 140.3$ & 0.48 \\
1200 & $319.8 \pm 249.4$ & $133.9 \pm 90.1$ & $390.3 \pm 154.6$ & $237.2 \pm 109.1$ & 0.69 \\
1800 & $136.1 \pm 66.2$ & $232.2 \pm 179.2$ & $148.5 \pm 103.2$ & $113.2 \pm 77.9$ & 0.32 \\
2400 & $186.0 \pm 71.7$ & $156.0 \pm 73.3$ & $178.4 \pm 137.0$ & $124.4 \pm 83.8$ & 0.17 \\
Mean & $214.7 \pm 94.0^{\mathrm{a}}$ & $221.1 \pm 89.1^{\mathrm{a}}$ & $264.9 \pm 105^{\mathrm{a}}$ & $254.1 \pm 107^{\mathrm{a}}$ &
\end{tabular}

a,b,c Different letters in columns indicate significant differences among treatments $(p<0.05)$. 
TABLE 5

Variation of volatile fatty acids $(\mathrm{mM} / \mathrm{l})$

\begin{tabular}{|c|c|c|c|c|c|}
\hline \multicolumn{6}{|c|}{ Acetic acid } \\
\hline Hour & $0 \% \mathrm{MA}$ & $10 \% \mathrm{MA}$ & $20 \% \mathrm{MA}$ & $30 \% \mathrm{MA}$ & SEM \\
\hline 0600 & $73.29 \pm 14.36$ & $73.77 \pm 8.64$ & $63.65 \pm 8.88$ & $56.54 \pm 3.05$ & 4.14 \\
\hline 1200 & $78.16 \pm 18.40$ & $79.15 \pm 10.58$ & $73.02 \pm 3.93$ & $61.69 \pm 4.58$ & 4.00 \\
\hline 1800 & $72.45 \pm 11.41$ & $67.60 \pm 10.82$ & $58.85 \pm 8.04$ & $56.67 \pm 12.20$ & 3.70 \\
\hline 2400 & $53.71 \pm 17.28$ & $48.04 \pm 14.75$ & $46.47 \pm 11.10$ & $43.01 \pm 7.87$ & 2.23 \\
\hline Mean & $69.4 \pm 5.38^{\mathrm{a}}$ & $67.1 \pm 6.78^{a b}$ & $60.5 \pm 5.52^{b}$ & $54.5 \pm 4.00^{\mathrm{c}}$ & \\
\hline \multicolumn{6}{|c|}{ Propionic acid } \\
\hline 0600 & $25.11 \pm 9.80$ & $21.40 \pm 5.96$ & $19.32 \pm 5.28$ & $24.75 \pm 2.06$ & 1.39 \\
\hline 1200 & $30.02 \pm 11.11$ & $23.47 \pm 6.28$ & $22.08 \pm 4.88$ & $17.20 \pm 4.07$ & 2.64 \\
\hline 1800 & $25.50 \pm 7.64$ & $19.32 \pm 3.84$ & $16.49 \pm 5.25$ & $14.26 \pm 7.00$ & 2.43 \\
\hline 2400 & $15.44 \pm 7.18$ & $12.25 \pm 5.67$ & $12.73 \pm 5.69$ & $9.58 \pm 3.89$ & 1.20 \\
\hline Mean & $24.0 \pm 6.14^{\mathrm{a}}$ & $19.1 \pm 4.88^{\mathrm{abc}}$ & $17.7 \pm 4.00^{\mathrm{bc}}$ & $16.4 \pm 6.36^{c}$ & \\
\hline \multicolumn{6}{|c|}{ Butyric acid } \\
\hline 0600 & $10.80 \pm 5.43$ & $6.1 \pm 2.313$ & $7.57 \pm 4.65$ & $8.13 \pm 1.21$ & 0.97 \\
\hline 1200 & $12.81 \pm 7.52$ & $8.14 \pm 3.99$ & $9.11 \pm 4.68$ & $10.04 \pm 3.29$ & 1.01 \\
\hline 1800 & $13.18 \pm 6.94$ & $8.33 \pm 4.08$ & $8.28 \pm 3.74$ & $9.87 \pm 3.19$ & 1.15 \\
\hline 2400 & $8.73 \pm 5.01$ & $5.65 \pm 4.26$ & $6.03 \pm 3.83$ & $7.12 \pm 4.20$ & 0.69 \\
\hline Mean & $11.4 \pm 2.05^{\mathrm{a}}$ & $7.1 \pm 1.37^{b}$ & $7.7 \pm 1.31^{\mathrm{b}}$ & $8.8 \pm 1.41^{b}$ & \\
\hline
\end{tabular}

a,b,c Different letters in columns indicate significant differences among treatments $(\mathrm{p}<0.05)$.

levels decreasing at 18:00 (12 hours after the first meal). The $20 \%$ and $30 \%$ MA treatments presented significant differences $(\mathrm{p}<0.05)$ with respect to $0 \%$ MA. Butyric acid increased from 06:00 to $18: 00 \mathrm{hr}$ in 0\% MA and 10\% MA and of $06: 00$ to $12: 00$ in $20 \%$ MA and $30 \%$ MA (Table 5). Levels of butyric acid were always lower in diets containing Sargassum spp. these showed significant differences $(\mathrm{p}<0.05)$ with $0 \%$ MA.

\section{DISCUSSION}

The chemical composition of the algae varies seasonally and annually in relation to environmental factors, geographic distribution and physiological variations (Jimenez \& Goñi 1999, Aguilera et al. 2005). Pérez (1999) reports variations in the chemical composition of Sargassum spp., collected in February, March, April and May in La Paz bay, in 1995. Their main components varied in a range of: protein 3.5 to $4.7 \%$, ash 26.5 to $31.7 \%$, crude fiber 10.2 to $11.4 \%$, and ether extract 0.1 to 0.4 . As Sargassum presents their maximum abundance, bidder size and completed their reproductive and life cycle at the end of spring, this seaweed is commonly collected then to do different experiments, as in the present research. Results about the chemical composition of Sargassum, collected at the end of spring, show the following values, protein 6.1 to $7.7 \%$, ash 31 to $38 \%$, crude fiber 6.5 to $9.3 \%$, and ether extract 0.34 to $1.8 \%$ (Carrillo et al. 2002, Marín et al. 2003, Casas-Valdez et al. 2006a, 2006b). The results obtained in this study (protein $7.7 \%$, ash $33.3 \%$, crude fiber $6.4 \%$ and ether extract $0.45 \%$ ) are similar to the ones previously mentioned. There are others components, like minerals analyzed in this study that also have seasonally and annually variations (Aguilera et al. 2005).

It seems that the palatability and taste of the different diets were not influenced by the 
inclusion of Sargassum meal as a feed ingredient, since there were not significant differences in feed intake. Water intake increased, as a result of the concentration of Sargassum included in the diet, particularly due to the large amount of $\mathrm{Na}$ and $\mathrm{K}$ in the algae. Consequently, the amount of urine excreted per day increased, being more abundant when sheep were fed with diets containing algae, as a result of the rise in water intake (Forbes 1995). Mora et al. (2009) also observed a progressive increase in the water intake and the urine excreted as the concentration of the alga Macrocystis pyrifera was higher (from $10 \%$ to $30 \%$ ) on diets given to goats. It is likely that fecal matter excreted by sheep was more humid in the $20 \%$ MA and $30 \%$ MA groups, because of the water intake increase.

The digestibility of the diets including Sargassum meal, showed an adequate utilization of algal nutrients $(79 \%$ to $74 \%)$. Our results suggest that values obtained for dry matter digestibility with diets supplemented with Sargassum spp. are similar to commonly used forages, like bean and soybean with $71.8 \%$ and $69.4 \%$, respectively (Valdez et al. 2002).

The concentration of seaweeds included in the diets, did not affect the digestibility of CP. The digestibility of cellular walls (FDN and FDA) increased, as a result of the concentration of Sargassum in the diet. This could be due to the presence of alginates, in the cellular walls of the algae.

The in situ digestibility allows determine whether degradation characteristics of vegetative species could be used to predict its nutritional value (Shem et al. 1995). The dry matter disappearance obtained in this work at $72 \mathrm{hr}$ varied from $65 \%$ to $68 \%$ as the concentration of Sargassum meal was increased. These values are in the range of those reported by Ramírez et al. (2000) for different shrubs from Baja California Sur, with a mean of 0.68 , and are closer to sorghum values (0.68) reported by Martínez et al. (1995). Mora et al. (2009) found a similar behavior in the dry matter disappearance when including the alga Macrocystis pyrifera on diets for goats, which rose from 0.73 to 0.80 as the concentration of the algae were increased from $10 \%$ to $30 \%$. This result is considered to be due to the fact that Macrocystis has a higher concentration of soluble carbohydrates (Rodríguez-Montesinos \& Hernández-Carmona 1991) than Sargassum (Casas-Valdez et al. 2006a), which is degraded faster in the rumen. Gojón et al. (1998) reported a $54.8 \%$ disappearance of Sargassum dry matter in an experiment conducted with bovines. This difference might be attributed to the fact that they evaluated the algae alone.

It is important to evaluate the kinetics of the digestion since it allows the proportion of nutrients of dry matter consumed that can be absorbed, and assimilated by the animal (Mertens 1993). The soluble fraction (a) was higher at all diets that included Sargassum with respect to the control diet. This is related to the high content of soluble ashes in the algae. According to Gojón et al. (1998) the minerals of Sargassum disappear from the nylon bag up to $78 \%$ at time 0 by diffusion.

The values of potentially digestible fraction of dry matter (b) obtained in the diets that included the alga (59\% to $64 \%$ ), are higher than those found by Ramírez et al. (2000) in nine shrubs from Northwest Mexico supplied to sheep $(15.5 \%$ to $54.7 \%)$, and similar to those reported by Galina et al. (2004) for diets that included maize, fish flour and urea (59\%). As well as those obtained by Mora et al. (2009) when supplying diets that included 10\%, 20\% and $30 \%$ of the alga $M$. pyrifera to goats (61 to $64 \%$ ).

There was not any significant difference on the degradable fraction among the diets used in this experiment, observing values from $70 \%$ to $80 \%$, what exhibits a low percentage of the indigestible fraction within each diet. These values were lower to those reported by Mora et al. (2009) (84\% to 87\%) when included $M$. pyrifera at concentrations from $10 \%$ to $30 \%$ on diets for goats. This could be related to the high content of ashes and soluble carbohydrates in Macrocystis (Mora et al. 2009).

The highest values of effective degradation were obtained at a disappearance or passage 
rate (fraction $/ \mathrm{hr}$ ) of $0.02 / \mathrm{hr}$ in comparison to the rates of $0.05 / \mathrm{hr}$ and $0.08 / \mathrm{hr}$; similar to the results obtained by Mora et al. (2009) with a diet containing $M$. pyrifera supplied to goats. Because when the flow is slower, it allows the feed to have a longer retention time in the rumen, obtaining a better degradation, as Forbes (1995) mentions that digestibility is the product of the retention time.

The rise in ruminal $\mathrm{pH}$ in sheep fed with marine algae could be as a consequence of the greater water consumption as mention Casas et al. (2003) and Mora et al. (2009). Furthermore, the addition of feedstuff with large amounts of starch or soluble carbohydrates will result in lower $\mathrm{pH}$ values (Fimbres et al. 2002, Giri et al. 2004) compared to diets with a prevalence of cellulose or other carbohydrates that are metabolized slowly. The proportion of Sargassum spp. in the diet affected positively ruminal $\mathrm{pH}$, because it favors a neutral $\mathrm{pH}$ that helps cellulolytic bacteria replication, which are responsible for the degradation of the cellulose in the feed (Weimer 1996).

Obara et al. (1991) suggested that lower levels of ruminal $\mathrm{NH}_{3} \mathrm{~N}$ are associated to increased rumen fermentation rates by stimulating an increased $\mathrm{NH}_{3} \mathrm{~N}$ uptake for microbial protein synthesis. In this study, ruminal $\mathrm{NH}_{3} \mathrm{~N}$ levels for sheep fed with Sargassum spp. were higher than the critical level $(20 \mathrm{mg} / \mathrm{l})$ suggested by Satter \& Slyter (1974) for microbial protein synthesis and digestibility.

The total VFA's concentration varies due to several factors. This may decline to a minimum $30 \mathrm{mM}$ or rise above $200 \mathrm{mM}$, but it is normally between 70 and $130 \mathrm{mM}$. The values obtained in this study fell within this range, except at 24:00 hr when VFA's concentration was below $70 \mathrm{mM}$ in treatments with Sargassum meal. Volatile fatty acids concentration in the rumen at any given time reflects the balance between production and loss rates. Immediately after feed intake, VFA's production exceeds the loss and the concentration increases, but subsequently this situation is reversed and VFA's concentration falls (France \& Siddons 1993), as was observed in this work. However, the acetate:propionate:butyrate molar proportions in VFA's obtained with diets containing Sargassum spp. were always lower than those in the control group. This can be explained because VFA's are produced in the rumen as end-products of microbial fermentation. Therefore, it is likely that Sargassum polysaccharides, namely mannuronic and guluronic acids from alginate, the fucose and xylose (soluble polysaccharide), were not fully degraded by microbial populations in the rumen.

It is concluded that the marine algae Sargassum spp. meal can be used as a feed supplement for sheep, especially in tropical and subtropical regions where this marine algae is available.

\section{ACKNOWLEDGMENTS}

The author Margarita Casas is grateful to Comisión de Fomento a las Actividades Académicas and Estímulo al Desempeño a la Investigación fellowships of Instituto Politécnico Nacional. Alejandro Marín was granted with a scholarship from Programa de Formación de Investigadores of Instituto Politécnico Nacional and Consejo Nacional de Ciencia y Tecnología.

\section{RESUMEN}

El objetivo de este estudio fue evaluar la harina del alga marina Sargassum como alimento para ovejas, midiendo la digestibilidad in vivo, la degradabilidad de la materia seca, así como el pH y los ácidos grasos volátiles en rumen. El alga Sargassum utilizada en este experimento, fue recolectada a finales de la primavera, cuando esta alga es más abundante, alcanza su mayor talla y ha completado su ciclo reproductivo. Se recolectaron manualmente, cuatro toneladas (peso húmedo) de la zona intermareal en la Bahía de La Paz, Baja California Sur, México. Estas algas fueron secadas directamente al sol y molidas en un molino de martillos, para obtener la harina. Se utilizaron cuatro borregos Pelibuey fistulados, distribuidos en un arreglo factorial de 4 $x$ 4. Los animales fueron alimentados diariamente con dietas que contenían el alga marina (AM) Sargassum a diferentes niveles $(0,10,20$ y $30 \%)$. El consumo de alimento no se vio afectado con la inclusión del alga $(\mathrm{p}>0.05)$. El consumo de agua y la excreción de orina se incrementaron conforme aumentó la concentración de AM en las dietas $\left(\mathrm{p}<0.05 ; \mathrm{r}^{2}=0.54\right.$ and $\mathrm{r}^{2}=0.74$, respectivamente). En todos los tratamientos la digestibilidad de la materia seca fue de 
$74 \%$ a $79 \%$, la digestibilidad de la proteína cruda fue de $85 \%$ a $88 \%$. La digestibilidad de la fibra ácido detergente $(59 \%-65 \%)$ y de la neutro detergente $(55 \%-66 \%)$ fue mayor en todos los tratamientos con AM, lo mismo ocurrió con el $\mathrm{pH}$ en rumen $(\mathrm{p}<0.05)$. La concentración de amonio en rumen no se vio afectada por AM ( $>00.05)$. La concentración de ácidos grasos volátiles se redujo en todos los tratamientos con AM $(\mathrm{p}<0.05)$. El alga marina Sargassum spp. puede ser usada como complemento alimenticio para ovejas, especialmente en las regiones tropicales y subtropicales donde está disponible.

Key words: alga marina, Sargassum, ovinos, digestibilidad, fermentación ruminal, ácidos grasos volátiles.

\section{REFERENCES}

Aguilera, M.M., M. Casas-Valdez, S. Carrillo, B. González \& F. Pérez-Gil. 2005. Chemical composition and microbiological assay of marine algae Enteromorpha spp. as potential food source. J. Food Compos. Anal. 18: 79-88.

AOAC (Association of Analytical Chemists). 2000. Official Methods of Analysis of Association of Analytical Chemist, Horwitz, W., Gaithersburg, Maryland, USA.

Arieli, A., D. Skland \& G. Kissil. 1993. A note on the nutritive value of Ulva lactuca for ruminants. Anim. Prod. 57: 329-331.

Carrillo, S., M. Casas, F.R. Pérez-Gil \& I. Sánchez. 2002. Algas marinas de Baja California Sur, México: Valor nutrimental. Arch. Latinoamer. Nutr. 52: 400-405.

Casas, M., H. Hernández, A. Marín, R.N. Águila \& S. Carrillo. 2003. Use of Sargassum spp. algae as supplement for goats cattle, p. 263. XIII Congreso Latinoamericano de Nutrición. Acapulco, Guerrero, Mexico.

Casas-Valdez, M., H.E. Hernández-Contreras, A. Marín-Alvarez, R.N. Águila-Ramírez, C.J. Hernández-Guerrero, I. Sánchez-Rodríguez \& S. Carrillo-Domínguez. 2006a. El Alga marina Sargassum (Sargassaceae): una alternativa tropical para la alimentación de ganado caprino. Rev. Biol. Trop. 54: 83-92.

Casas-Valdez, M., G. Portillo-Clark, N. Águila-Ramírez, S. Rodríguez-Astudillo, I. Sánchez-Rodríguez \& S. Carrillo-Domínguez. 2006b. Efecto del alga marina Sargassum spp. sobre las variables productivas y la concentración de colesterol en el camarón café, Farfantepenaeus californiensis (Holmes, 1900). Rev. Biol. Mar. Oceanogr. 41:97-105.
Clesceri, L., A. Grenberg \& R. Trussel. 1989. Standard methods for examination of water and wastewater. American Public Health Association, Washington, DC, USA.

Fimbres, H., J.R. Kawas, G. Hernández-Vidal, J.F. PicónRubio \& C.D. Lu. 2002. Nutrient intake, digestibility, mastication a ruminal fermentation of lambs fed finishing ration with various forage levels. Small Ruminant Res. 43: 275-281.

Forbes, J.M. 1995. Voluntary food intake and diet selection in farm animals. CAB International, Wallingford, Oxford, England.

France, J. \& R.C. Siddons. 1993. Volatile fatty acid production, p. 107-121. In J.M. Forbes \& J. France (eds.). Quantitative aspects of ruminant digestion and metabolism. CAB International, Wallingford, Oxford, England.

Galina, M.A., M. Guerrero, C.D. Puga \& G.F.W. Haenlin. 2004. Effects of slow-intake urea supplementation on goat kids pasturing natural Mexican rangeland. Small Ruminant Res. 55: 85-95.

Ganzon-Fortes, E.T., R.R. Campos \& J. Udarbe. 1993. The use of Philippine seaweeds in agriculture. Appl. Phycol. Forum 10: 6-7.

Giri, S.S., S. Jaggi \& N.N. Pathakl. 2004. Feeding of grain less diets containing different nitrogen sources to crossbred growing bulls: effects on rumen fermentation pattern, microbial enzyme activity and ciliate protozoa population. Anim. Feed Sci. Technol. 118: 187-200.

Gojón, B.H., D. Siqueiros \& H. Hernández. 1998. In situ ruminal digestibility and degradability of Macrocystis pyrifera and Sargassum spp. in bovine livestock. Cien. Mar. 24: 463-481.

Hansen, H.R., B.L. Hector \& J. Feldmann. 2003. A qualitative and quantitative evaluation of the seaweed diet of North Ronaldsay sheep. Anim. Feed Sci. Technol. 105: 21-28.

Harmon, D.L. \& C.J. Richards. 1997. Considerations for gastrointestinal cannulations in ruminants. J. Anim. Sci. 75: 2248-2255.

Jimenez, E.A. \& I.C. Goñi. 1999. Evaluación nutricional y efectos fisiológicos de macroalgas marinas comestibles. Arch. Latinoamer. Nutr. 49: 114-120.

Kuehl, R.O. 1999. Design of experiments: statistical principles of research design and Analysis. Duxbury/ Thomson Learning, Pacific Grove, California, USA. 
Marín, A., M. Casas, S. Carrillo, H. Hernández \& A. Monroy. 2003. Performance of sheep fed rations with Sargassum spp. algae. Cuban J. Agric. Sci. 37:119-123.

Martínez, R.G., M. Núñez, A. Herbele \& J. Márquez. 1995. Evaluación de forrajes para la sustitución de la alfalfa en la región árida de México. I. Digestibilidad, p. 244-249. In Memorias de la Asociación Mexicana de Producción Animal. Mexico, D.F., Mexico.

Mertens, D.R. 1993. Rate and extent of digestion, p. 13-51. In J.M. Forbes \& J. France (eds.). Quantitative Aspects of Ruminant Digestion and Metabolism. CAB International, Wallingford, Oxford, England.

Mora, C.N., M. Casas-Valdez, A. Marín, R. Aguila, I. Sánchez, H. Hernández \& L. Sanginés. 2009. The kelp Macrocystis pyrifera as nutritional supplement for goats. Rev. Cientif. FVC-LUZ. XIX: 1-8.

NRC (National Research Council). 1996. Nutrient Requirements of Beef Cattle. Academy, Washington, DC, USA.

NOM-117-SSA1-1994. 1994. Norma Oficial Mexicana. Método de Prueba para la determinación de cadmio, arsénico, plomo, estaño, cobre, hierro, zinc y mercurio en alimentos, agua potable y agua purificada por espectrometría de absorción atómica. Gobierno Federal, México.

Obara, Y., D.W. Dellow \& J.V. Nolan. 1991. The influence of energy-rich supplements on nitrogen kinetics in ruminants, p. 515-540. In: T. Tsuda, Y. Sasaki, I. Kawashima (eds.). Physiological Aspects of Digestion and Metabolism in Ruminants. Proc. Seventh Symp. Academic, San Diego, California, USA.

Orskov, E.R. \& L. McDonald. 1979. The estimation of protein degradability in the rumen form incubation measurements weighed according to the rate of passage. J. Agric. Sci. 92: 499-503.

Pérez, R.C. 1999.Composición química de Sargassum spp. colectado en la Bahía de La Paz, B.C.S., y la factibilidad de su aprovechamiento en forma directa o como fuente de alginato. Tesis de Maestría, La Paz, Baja California Sur, México.

Ramírez, R.G., R.R. Neira, R.A. Ledezma \& C.A. Garibaldi. 2000. Ruminal digestion characteristics and effective degradability of cell wall of browse species from northeastern Mexico. Small Ruminant. Res. 36: 49-55.

Rodríguez-Montesinos, Y.E. \& G. Hernández-Carmona. 1991. Seasonal and geographic variations of Macrocystis pyrifera chemical composition at the western coast of Baja California. Cien. Mar. 17: 91-107.

SAS. 1985. SAS/STAT guide for personal computers (Version 6a. ed.). SAS Inst. Inc. Cary, N.C.

Satter, L.D. \& L.L. Slyter. 1974. Effect of ammonia concentration on rumen microbial protein production in vitro. Br. J. Nutr. 32: 199-208

Shem, M.N., E.R. Orskov \& A.E. Kimambo. 1995. Prediction of voluntary dry-matter intake, digestible dry-matter intake and growth rate of cattle from the degradation characteristics of tropical foods. Anim. Sci. (Pencaitland) 60: 65-74.

Stern, M.D., A. Bach \& S. Calsamiglia. 1997. Alternative techniques for measuring nutrient digestion in ruminants. J. Anim. Sci. 75: 2256-2276.

Tejada, I.H. 1985. Manual de laboratorio para análisis de ingredientes utilizados en la alimentación animal, Patronato de Apoyo a la Investigación y Experimentación Pecuaria en México, INIFAP, Secretaría de Agricultura y Recursos Hidráulicos, Mexico, D. F., Mexico.

Valdez, L.M., V.L. Almeida, G.U. Maldonado, G.E. Vázquez, A.M. Luque \& L.J. Portillo. 2002. Efecto del frijol (Phaseolus vulgaris) de rezaga cocido en la digestibilidad aparente de la fibra en cabras lecheras, p. 273-279. In L.M. Valdez, V.L. Almeida, G.U. Maldonado, G.E. Vázquez, A.M. Luque \& L.J. Portillo (eds.). Memorias de la XX Reunión Nacional Sobre Caprinocultura. Culiacán, Sinaloa, Mexico.

Weimer, P.J. 1996. Why don't ruminal bacteria digest cellulose faster? J. Dairy Sci. 79: 1496-1502.

Yahaya, M.S., J. Takahasi, S. Matsuoka \& A. Kibon. 1999. Effect of supplementary feeding of cotton seed cake on feed intake, water consumption and work output of work bulls in Borno State, Nigeria. Anim. Feed Sci. Technol. 79: 137-143. 
